\title{
ЕКСПЕРИМЕНТАЛЬНА МОДЕЛЬ ЛІКУВАННЯ ХРОНІЧНОЇ КРИТИЧНОЇ ІШЕМІЇ ТКАНИН НИЖНЬОЇ КІНЦІВКИ З ВИКОРИСТАННЯМ КУЛЬТУРИ СТОВБУРОВИХ КЛІТИН, ОДЕРЖАНИХ З ЖИРОВОЇ ТКАНИНИ
}

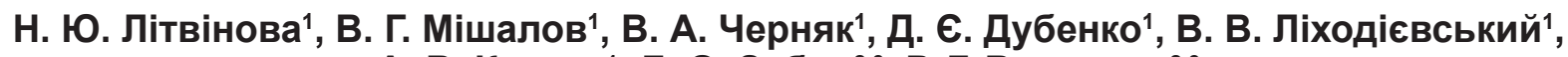 \\ А. В. Корсак', Д. О. Зубов ${ }^{2,3}$, Р. Г. Васильєв ${ }^{2,3}$ \\ ${ }^{1}$ Національний медичний університет імені О. О. Богомольця МОЗ України, \\ ${ }^{2}$ /нститут генетичної та регенеративної медицини НАМН України, \\ ${ }^{3}$ Біотехнологічна лабораторія ilaya. regeneration, Медична компанія ilaya, м. Київ

\section{EXPERIMENTAL MODEL OF TREATMENT OF CHRONIC CRITICAL ISCHEMIA OF THE LOWER EXTREMITY TISSUE, USING CULTURE OF STEM CELLS, OBTAINED FROM THE FAT TISSUE}

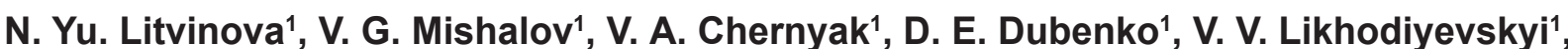
A. V. Korsak', D. O. Zubov'2,3, R. G. Vasilyev',3

'Bogomolets National Medical University,

${ }^{2}$ Institute of Genetic and Regenerative Medicine,

${ }^{3}$ Biotechnological Laboratory ilaya. regeneration, Medical Company ilaya, Kyiv

\section{Реферат}

Вступ. Захворювання периферійних артерій (ЗПА) є важливою медико-соціальною проблемою, що потребує розробки нових видів терапії, зокрема, використання аутологічних стовбурових клітин.

Мета. Вивчити морфофрункціональний стан нижніх кінцівок кролів, у яких моделювали хронічну критичну ішемію тканин нижніх кінцівок (ХКІНК) та застосовували культуру аутологічних стовбурових клітин, одержаних з їх жирової тканини (ADSCs).

Матеріали і методи. У дослідження включені 18 кролів-самиць, розподілених на 3 групи: псевдооперованих (I), оперованих яким вводили ізотонічний розчин $\mathrm{NaCl}$ (II), оперованих, яким вводили ADSCs (III). Морфофрункціональний стан тазових кінцівок оцінювали за даними дуплексної фрлометрії, функціональних тестів та морфологічного дослідження.

Результати. У тварин III групи спостерігали часткове відновлення функції тазової кінцівки та покращення стану м'язової тканини, чого не було у тварин II групи. В III групі відзначене припинення прогресування некротичних процесів та часткова епітелізація трофрічних виразок.

Висновки. Використання ADSCs при моделюванні ХКІНК у кролів сприяло відновленню функції тазової кінцівки, що проявлялося якісними й кількісними змінами морфофункціональних показників через 5 тиж після введення стовбурових клітин.

Ключові слова: хронічна критична ішемія тканин нижніх кінцівок; захворювання периферійних артерій; ADSCs; експеримент.

Abstract

Introduction. Diseases of peripheral arteries constitute important medico-social problem, what demands elaboration of new types of therapy, and application of autologous stem cells in particular.

Objective. To study a morphofunctional state of the lower extremities in rabbits, in whom chronic critical ischemia of the lower extremities tissues was simulated and a culture of adipose-derived stem cells (ADSCs), obtained from their tissue, was applied.

Materials and methods. In the investigation 18 rabbits-females, divided on 3 groups, were studied: pseudooperated (I), operated, to whom isotonic solution of $\mathrm{NaCl}$ was injected (II), and operated, to whom ADSCs was injected (III). Morphofunctional state of pelvic extremities was estimated in accordance to the duplex flowmetry data, and functional tests and morphological investigation were conducted.

Results. In laboratory animals of group III a partial restoration of the pelvic extremity function and improvement of the muscle tissue state was observed, what was absent in laboratory animals group II. In group III the arrest of the necrotic processes progress and partial epithelization of trophic ulcers were noted.

Conclusion. Application of ADSCs while simulation of chronic critical ischemia of tissues in rabbits have promoted restoration of the pelvic extremity function, demonstrated by qualitative and quantitative changes in morphofunctional indices in 5 weeks after injection of stem cells.

Keywords: chronic critical ischemia of the lower extremities tissues; diseases of peripheral arteries; ADSCs; experiment.

Захворювання периферійних артерій (ЗПА) є важливою медико-соціальною проблемою як для пацієнтів 3 країн 3 низьким рівнем доходів населення, так і розвинених краін. За даними великих статистичних досліджень, більш ніж у 250 млн. пацієнтів у світі діагностують ЗПА, причому, переважно в країнах, що розвиваються. Глобальне поширення ЗПА збільшилося на 24\% з 2000 до 2010 р., $з 164$ до 202 млн.
Близько 140,8 млн. (70\%) хворих живуть у регіонах з низьким і середнім рівнем доходів на душу населення, частота ЗПА у них на 29\% більша порівняно з минулим десятиліттям. 
Проте, в регіонах з високим рівнем доходів також спостерігають збільшення частоти 3ПА - на 13\% протягом десятирічного періоду [1, 2].

В Україні 3ПА, зокрема, ХКІНК $€$ важливою медичною та економічною проблемою, оскільки вони спричиняють ранню інвалідизацію та збільшення смертності пацієнтів працездатного віку. Значне поширення ЗПА та недостатня ефективність сучасних методів лікування (хірургічні втручання 3 відновлення прохідності артеріальних судин, створення обхідних шунтів) зумовлюють необхідність проведення подальших досліджень і розробки принципово нових видів терапіі ЗПА [3].

Використання аутологічних стовбурових клітин $є$ відносно новим перспективним методом лікування ЗПА, проте, широке застосування і впровадження цієї методики в клінічну практику обмежене недостатньою кількістю доклінічних експериментальних досліджень [4].

Мета дослідження: вивчити морфофункціональний стан нижніх кінцівок кролів, у яких моделювали ХНІНК, до і після застосування культури сингенних стовбурових клітин, одержаних з жирової тканини (ADSCs).

\section{МАТЕРІАЛИ I МЕТОДИ ДОСЛІДЖЕННЯ}

Дослідження проведене на 18 кролях-самицях породи Шиншила, масою тіла $(3,2 \pm 0,6)$ кг, віком $(16 \pm$ 5) міс, яких тримали у стандартних умовах віварію, за природного освітлення.

Відповідно до мети роботи, тварини розподілені на три групи: I група - псевдооперовані (виконаний розріз шкіри без судинного етапу), лікування не проводили ( $\mathrm{n}=3)$; II група - оперовані, тваринам вводили ізотонічний розчин $\mathrm{NaCl}(\mathrm{n}=5)$; III група - оперовані, тваринам вводили $\operatorname{ADSCs}(n=10)$.

Оперативне втручання виконували під загальною анестезією, згідно Guide for the Care and Use of Laboratory Animals published by the US National Institutes of Health. Для наркозу використовували ксилазин (10 мг/кг внутрішньом'язово) та кетамін (70 мг/кг внутрішньом'язово).
Премедикацію здійснювали шляхом введення димедролу та анальгіну (10 мг/кг внутрішньом'язово). Всі тварини оперовані за методикою створення анатомічної моделі ХКІНК [3].

Під час оперативного втручання в одного кроля групи II вилучена жирова клітковина 3 заочеревинного простору для подальшого вирощування ADSCs [5].

Під час оперативного втручання проводили біопсію м'язів стегна та гомілки оперованої кінцівки [6].

Через 4 тиж після оперативного втручання та встановлення стадії ХКІНК тваринам групи III вводили культивовані сингенні ADSCs у 4 точки на стегні і гомілці у найбільші м'язові масиви.

Через 5 тиж після оперативного втручання в усіх тварин оцінювали стадію ішемізації тканин оперованої кінцівки за даними гістологічного дослідження, стан мікроциркуляції методом лазерної флоуметрії (апарат ЛАКК-02), стан тазової кінцівки за допомогою функціональних методів (визначення гомілково-стегнового кута під час гравітаційної екстензії кінцівки, ступеня розходження пальців при приземленні лапи на тверду горизонтальну поверхню, вираженості рефлексів нижньої кінцівки) [6].

Через 5 тиж після введення ADSCs в усіх тварин повторно проводили інструментальні і функціональні тести для оцінки стану оперованої кінцівки.

Після цього тварин виводили 3 експерименту шляхом передозування тіопентал-натрію (200 мг/кг внутрішньоочеревинно).

Макроскопічно оцінювали стан судин та м'язів нижніх кінцівок 3 обох боків, після чого для гістологічного дослідження забирали фрагменти м'язів стегна та задньої групи гомілки. Матеріал фіксували у 10\% розчині нейтрального формаліну, виготовляли поперечні заморожені зрізи товщиною 20 - 30 мкм за допомогою мікротома-кріостата МК25 (Ростех, Росія). Зрізи забарвлювали гематоксиліном та еозином. Препарати фотографували за допомогою мікроскопа Olympus BX51 та цифрової фотокамери Olympus Zoom 4040 (Olympus, Японія). Оцінювали площу м'язових волокон та їх периметр. Аналіз мікрофото проводили за допомогою програми для аналізу біомедичних зображень ImageJ ver. 1.50 (National Institutes of Health, США, open-source).

Після цього проведена аутопсія 3 пошаровим дослідженням уражених кінцівок, вилученням суміжних груп м'язів на оперованих та інтактних кінцівках, порівняльним зважуванням, макрометричною візуальною оцінкою та сантиметричною об'ємною оцінкою суміжних груп м'язів на обох кінцівках.

Кровопостачання тазової кінцівки кроля відповідає такому у ссавців (зокрема, у людини), крім деяких деталей. Колатералі між гілками стегнової артерії (СА) з басейну зовнішньої клубової артерії і гілками внутрішньої клубової артерії не так розвинений як, наприклад, у мишей [7] У кролів клінічно важливою артерією тазової кінцівки є велика підшкірна артерія (ВПА), що є гілкою СА до переходу ії у підколінну артерію. Вона відповідає за васкуляризацію задньої групи м'язів стегна та, спускаючись нижче колінного суглоба, розгалужується на пальцеві артерії. ВПА компенсує слабий розвиток задньої великогомілкової артерії і майже немає колатеральних зв'язків 3 глибокою стегновою артерією та іншими великими гілками СА. Через це, повне перекриття просвіту СА вище місця відгалуження ВПА спричиняе гостру артеріальну ішемію тазової кінцівки та унеможливлює моделювання ХКІНК $[8,9]$.

За даними нашого спостереження, у тварин виявляли різні варіанти анатомії магістральних судин стегнової ділянки, залежно від чого обирали тактику хірургічного втручання. Основним критерієм для звуження СА $є$ іiі діаметр. В досліджуваних групах він становив від 0,5 до 2 мм. Також спостерігали різні варіанти розташування судинно-нервового пучка стегна (від підшкірного до глибокого, що містився у м'язовому масиві медіальної поверхні стегна). Для створення моделі ХКІНК виконували такі дії: в умовах асептики та антисептики, попередньо звільнивши від шерсті ділянку оперативного втручання з використанням депіляційного крему, на медіальній поверхні стегна, на 1 см нижче пахвинної зв'язки, робили розріз довжиною 4 - 6 см. Після тупої дисекції присе- 
редньої групи м'язів стегна отриманий доступ до нервого-судинного пучка. Шляхом тупої дисекції, гідропрепарування мобілізували СА. Вище місця відгалуження ВПА на СА накладали лігатуру (Prolene 5/0). Ступінь стенозу контролювали за допомогою шкали-лінійки. Після завершення судинного етапу операції видаляли ділянку $(1 \times 0,5$ см) медіального м'яза стегна для гістологічного дослідження. Рану зашивали наглухо (шовк 4/0) безперервним швом, накладали щільну асептичну пов'язку, додатково закріплювали іiі для запобігання механічного пошкодження після операції. Через 2 год після операції вводили анальгін 10 мг/кг внутрішньом'язово. В усіх кролів проводили антибіотикопрофілактику шляхом введення цефтріаксону (50 мг/кг, внутрішньом'язово, один раз на добу протягом 3 діб) [3].

Утримання, маркування та всі маніпуляції проводили 3 дотриманням правил виконання робіт з використанням експериментальних тварин, затверджених наказом МОНМС України № 249 від 01.03.2012 “Про затвердження Порядку проведення науковими установами дослідів, експериментів на тваринах", та принципів Директиви 2010/ 63/EU Європейського парламенту та Ради Європи про захист тварин, що використовують з науковою метою.

Культура стовбурових клітин, одержаних з жирової тканини кролів (ADSCS).

Культура ADSCs отримана 3 мінімального фрагмента заочеревинного білого жиру кролів об'ємом до $3 \mathrm{~cm}^{3}$. Жировий фрагмент двічі промивали фосфатно-сольовим буфером 3 розчином антибіотиків/антимікотиків, 1000 Од/мл (BioWest, Франція). Промитий жир подрібнювали скальпелем та перетравлювали в суміші ферментів - 0,1\% пронази та 0,1\% колагенази типу IA в середовищі DMEM: F12, доповненої 2\% FBS (усі виробництва Sigma-Aldrich, США) протягом 1 год при температурі $37^{\circ} \mathrm{C}$ за швидкості 200 об./хв в шейкері-інкубаторі (Biosan, Латвія). Реакційну суміш розбавляли п'ятиразово фосфатно-сольовим буфером (Sigma-Aldrich, США) та центрифугували при 800 g протягом 10 $\mathrm{xB}$ при температурі $+4^{\circ} \mathrm{C}$ в холодовій центрифузі 5810R (Eppendorf,
Німеччина). Клітини ресуспендували у ростовому середовищі та вливали в культуральний флакон Т $75 \mathrm{~cm}^{2}$ (SPL, Корея). Первинну культуру пересаджували у культуральні флакони 2 × T 75 (SPL, Корея). Терапевтичні дози ADSC для всіх тварин нарощували протягом 20 діб. Одноразова терапевтична доза становила $5 \times 10^{6}$ клітин на одну тварину.

Ростове середовище для ADSC складається $3 \alpha$-MEM, 10\% FBS, 1 нг/ мл bFGF (Sigma-Aldrich, США), 100 Од/мл розчину антибіотиків/антимікотиків (BioWest, Франція). Субкультивування клітин здійснювали сумішшю трипсину та розчину ЕДТА у співвідношенні 0,05\%:0,02\% у фосфатно-сольовому буфері (Sigma-Aldrich, США). Щільність посіву становила $10^{3}$ клітин в $1 \mathrm{~cm}^{2}$.

Усі типи клітин вирощували в мультигазовому інкубаторі (Binder CВ210, Німеччина) в атмосфері 5\% $\mathrm{CO}_{2}$ та $5 \% \mathrm{O}_{2}$ і насичуючій вологості $97 \%$.

Диференціювання клітин за ортодоксальними напрямками

Для встановлення приналежності клітин та відповідних функціональних характеристик виконували стандартні тести прямого диференціювання за трьома ортодоксальними напрямками, притаманними мультипотентним мезенхімальним стромальним клітинам - адипогенним, остеогенним та хондрогенним [10].

Адипогенне диференціювання проводили в середовищі: DMEMHG (4,5 г/л), 10\% FBS, 1 мкмоль дексаметазону, 200 мкмоль індометацину, 500 мкмоль ізобутилметилксантину, 5 мкг/мл інсуліну (SigmaAldrich, США) та 5\% донорської сироватки коней (BioWest, Франція). Через 14 діб клітини фіксували і забарвлювали. Для виявлення адипогенного диференціювання клітини забарвлювали 0,5\% розчином барвника Oil Red O для нейтральних внутрішньоклітинних ліпідів (SigmaAldrich, США) [11].

Остеогенне диференціювання проводили в середовищі: DMEM 3 низьким вмістом глюкози (1 г/л), 10\% FBS, 100 нмоль дексаметазону, 10 ммоль $\beta$-гліцерофосфату та 50 мкг/мл аскорбат-2-фосфату (Sigma-Aldrich, США). Через 21 добу клітини фіксували та забарвлювали.
Для виявлення остеогенного диференціювання клітини забарвлювали 2\% розчином барвника Alizarin Red $\mathrm{S}$ для відкладень кальцифікованого позаклітинного матриксу (SigmaAldrich, США) [11].

Хондрогенне диференціювання проводили з використанням методу мікромас-культури протягом 21 доби; 300000 клітин центрифугували протягом 14 хв 3 швидкістю 2000 об./ хв для одержання осаду об'ємом 15 мл в пробірках (Nunc, CША). Осади клітин (мікромасу) культивували в хондрогенному індукційному середовищі, що містило DMEM 3 глюкозою 4,5 г/л (РАА, Німеччина) з додаванням 50 мкг/мл аскорбат-2-фосфату (Sigma-Aldrich, США), 40 мкг/ мл L-проліну (Sigma-Aldrich, CША), 100 мкг/мл натрію пірувату (SigmaAldrich, США), 10 нг/мл rhTGF- $\beta 3$ (Sigma, США), 10-7 моль дексаметазонy (Sigma-Aldrich, CША), 1\% ITS, що містив 6,25 мкг/мл інсуліну, 6,25 мкг/ мл трансферину, 6,25 нг/мл натрію селеніту (Gibco, CША), 1,25 мг/мл альбуміну сироватки биків (SigmaAldrich, США) [7]. Одержані хондроїди різали на мікротомі, зрізи забарвлювали альціановим синім (SigmaAldrich, США) для виявлення кислих глікозаміногліканів.

Мікроскопію виконували на інверсійному флуоресцентному мікроскопі AxioObserver A1, оснащеному цифровою камерою AxioCamERc $5 \mathrm{~s}$ та програмним забезпеченням ZEN 2012 (Carl Zeiss, Німеччина).

Отримані статистичні дані аналізували за допомогою пакета SPSS Statistics Base v.22 (IBM, США). Величини оцінювали методами описової статистики. Для визначення виду розподілу ознак використаний критерій Колмогорова-Смирнова; відмінностей ознак в експериментальних групах - тест ANOVA; кількісних параметрів стану м'яза при порівнянні між групами - непараметричний критерій Манна-Уітні.

\section{РЕЗУЛЬТАТИ}

Після оперативного втручання у кролів груп II і III спостерігали різні стадії ХКІНК: у 7 кролів групи ІІІ (підгрупа IIIa) та 4 кролів групи II (підгрупа ІІа) виявлено ХКІНК без некротичних змін на оперованій кінцівці; у 3 кролів групи III (підгрупа IIIб) та 1 кроля групи II (підгрупа IIб) 
- ХКІНК з некротичними змінами (у 2 - виразку шкіри без інфікування, у 2 - суху гангрену нижньої третини гомілки). Цим кролям додатково вводили ADSCs у місця дефекту шкіри, в життездатні тканини вище місця патологічного процесу.

В підгрупі ІІІб через 5 тиж після введення ADSCs спостерігали загоєння виразок шкіри (наявність грануляцій, часткова епітелізація рани), тварина користувалася кінцівкою під час пересування; в групі ІІб загоєння виразок не було, відзначене прогресування некрозу гомілки до рівня верхньої третини.

За даними лазерної флоуметрії у тварин групи I показник мікроциркуляції оперованої кінцівки (виміри проводили у 2 точках на стегні, 2 - на гомілці та в ділянці післяопераційного рубця) становив у середньому $(14,5 \pm 1,1)$ ОД, у тварин групи II - $(9,6 \pm 1,6)$ ОД, групи III - $(11,2$ $\pm 0,9)$ ОД.

При визначенні ступеня розходження пальців при опусканні тварини на горизонтальну поверхню (рефлекс приземлення) більшою мірою він проявлявся у групах I і III (суб'єктивна оцінка). При визначенні рівня гравітаційної екстензії (в нормі - помірна флексія тазової кінцівки) виявлено майже повну відсутність довільної флексії у групі II та субфізіологічну флексію - в групі III. В групі І відхилень від норми не спостерігали.

При макроскопічному дослідженні оперованих тазових кінцівок встановлене значне розширення підшкірних судин (діаметр цих судин наближався до діаметра СА) у тварин групи III, що не спостерігали у тварин інших груп та на неоперованих кінцівках.

За даними морфологічного дослідження м'язів гомілки у кролів групи I в середній третині м'яза відзначений судинно-нервовий пучок, що складався 3 великої артерії, вени та

\section{REFERENCES}

1. Fowkes FGR, Rudan D, Rudan I, Aboyans V, Denenberg JO, McDermott MM, et al. Comparison of global estimates of prevalence and risk factors for peripheral artery disease in 2000 and 2010: a systematic review and analysis. Lancet. 2013 DOI:10.1016/S0140 6736(13)61249-50.

2. Hirsch AT, Duval S. The global pandemic of peripheral artery disease. Lancet 2013; DOI: 10.1016/S0140-6736(13)61576-7.

3. Litvinova N, Chernyak V, Dubenko D. Model formuvannya kontrolyovanoi ishemii nizhnyoi kintsivky u krolyka. Serce i sudyni. 2016;(4):61-65. [In Ukrainian].

4. Rigato M, Monami M, Fadini GP. Autologous cell therapy for peripher-
За даними статистичного аналізу, середня площа у тварин групи II достовірно більша, ніж у тварин групи I $(\mathrm{p}<0,05)$ та групи III $(\mathrm{p}=0,001)$.

Середній периметр м'язового волокна також найбільший і достовірно різнився від такого у кролів II групи порівняно з показником у тварин групи I ( $<$ 0,001) i III ( $\mathrm{p}=0,007)$.

\section{ОБГОВОРЕННЯ}

За результатами морфологічного дослідження, виявлений набряк м'язових волокон у кролів груп II і III, що розцінювали як прояв атрофії внаслідок ішемії. Застосування ADSCs у кролів групи III сприяло зменшенню набряку та кількості волокон з зміненою конфігурацією.

Результати функціональних тестів свідчили про певне відновлення функції оперованої кінцівки у кролів групи II (ступеня фізіологічних рефлексів), що зумовлене частковою регенерацією м'язової тканини. Оцінка стану мікроциркуляції свідчила про покращення підшкірного кровообігу у тварин групи III порівняно з таким у тварин групи II, що можна пов'язати, по-перше, з розвитком нового клінічно значущого колатерального кровообігу через систему судин шкіри і підшкірного прошарку, по-друге, з неоангіогенезом у власне м'язовій тканині $[12,13]$.

Наші дані корелюють 3 результатами інших дослідників, проте, вони використовували інші методи оцінки стану нижніх кінцівок (ангіографію) [6]. Новизною нашого дослідження $€$ використання сингенних стовбурових клітин, одержаних 3 жирової тканини, а не 3 кісткового мозку.

Таким чином, використання ADSCs за умови моделювання ХКІНК у кролів сприяло відновленню функції нижньої кінцівки, що проявлялося якісними і кількісними змінами морфофункціональних показників через 5 тиж після їх введення. al arterial disease:systematic review and meta-analysis of randomized, non-randomized, and non-controlled studies.Circ Res. 2017 Apr 14;120(8):1326-40. DOI: 10.1161/CIRCRESAHA.116.309045.

5. Lasala GP, Silva JA, Minguell JJ. Therapeutic angiogenesis in patients with severe limb ischemia by transplantation of a combination stem cell product. J Thorac Cardiovasc Surg. 2012;144:377-82.

6. Mikami S, Nakashima A, Nakagawa K, Maruhashi T, Iwamoto Y, Kajikawa M, Matsumoto T, et al. Bone-marrow mesenchymal stem cell implantation and endothelial function in a rabbit ischemic limb model. PLoSOne. 2013 Jul 4;8(7) https://doi.org/10.1371/journal. pone.0067739. 
7. Niiyama H, Huang NF, Rollins MD, Cooke JP. Murine model of hindlimb ischemia .Vis Exp. 2009(23):1035.

8. Jedenov VN. Anatomiya krolika. Moskva: Sovetskaya nauka; 1987. 293 p. [In Russian].

9. Gindze B.K. Atlas anatomii jivotnih. Leningrad: Selhozgiz ; 1937. 389 p.[In Russian]

10. Dominici M, Le Blanc K, Mueller I, Slaper-Cortenbach I, Marini F Krause D, et al. Minimal criteria for defining multipotent mesenchymal stromal cells. The International Society for Cellular Therapy position statement. Cytotherapy. 2006;8(4): 315-7.

11. Prockop DJ, Phinney DG, Bunnell BA. Mesenchymal stem cells: methods and protocols. Totowa, NJ: Humana Press; 2008. 192 p.
12. Motukuru V, Suresh KR, Vivekanand V, Raj S, Girija KR. Therapeutic angiogenesis in Buerger's disease (thromboangiitis obliterans) patients with critical limb ischemia by autologous transplantation of bone marrow mononuclear cells. J Vasc Surg. 2008;48 suppl:53-60.

13. Lara-Hernandez R, Lozano-Vilardell P, Blanes P, Torreguitart-Mirada N, Galmes A, Besalduch J. Safety and efficacy of therapeutic angiogenesis as a novel treatment in patients with critical limb ischemia. Ann Vasc Surg. 2010;24:287-94. 